\title{
Behaviors associated with cows more prone to produce milk with reduced stability to ethanol test due to feeding restriction
}

\author{
Comportamentos associados com vacas mais propensas a apresentar \\ leite com reduzida estabilidade ao álcool após restrição alimentar
}

\author{
Marcelo Tempel Stumpf ${ }^{\mathrm{I}}$ Vivian Fischer ${ }^{\mathrm{II}}$ Giovani Jacob Kolling ${ }^{\text {II }}$

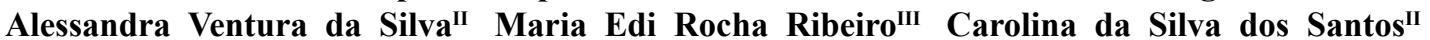

\section{ABSTRACT}

The experiment was carried out to identify changes in the behaviorr of lactating cows induced by severe feeding restriction and further refeeding that could serve as facilitators for the visual identification of cows more prone to produce milk with reduced stability. Twelve cows were separated into two groups: Control: full diet supply; Restriction: $50 \%$ of the full diet. Feed restriction lasted seven days (Period 1), with posterior supply of full diet for seven days (Period 2) for all treatments. Behavior was observed on the first and fifth days in each period from $08 \mathrm{~h} 40$ to 19h00. Ingestive and social behavior were monitored. Cortisol assessed stress levels. Analysis of variance and multifactorial statistical analyzes were performed. Adequate feed supply reduced stress, improved animals' welfare and milk stability to the ethanol test. Elevation in the incidence of behavior related with hunger, frustration and discomfort is an indicator of cows more prone to produce milk with reduced stability.

Key words: Bos taurus taurus, feeding restriction, ingestive behaviour, milk stability, social behaviour.

\section{RESUMO}

$O$ experimento foi conduzido para identificar alterações comportamentais de vacas lactantes submetidas à restrição alimentar severa e realimentação, as quais podem servir para identificação visual de vacas mais propensas a produzir leite de reduzida estabilidade ao álcool. Doze vacas foram separadas em dois grupos: controle: suprimento de dieta completa; restrição: $50 \%$ da dieta completa. A restrição alimentar durou sete dias (Período 1), com posterior suprimento de dieta completa por sete dias (Periodo 2) a todos os animais. O comportamento foi monitorado no primeiro e quinto dias de cada periodo, entre as 08h40min e 19h. Comportamentos ingestivo e social foram observados. Os níveis de cortisol foram utilizados para monitorar os niveis de estresse. Análises de variância e multifatorial foram realizadas. $O$ suprimento adequado da dieta reduziu estresse, aumentou o bem-estar animal, bem como a estabilidade do leite ao teste do álcool. Elevação na incidência de comportamentos relacionados à fome, frustração e desconforto é um indicador de vacas mais propensas a produzir leite com reduzida estabilidade.

Palavras-chave: Bos taurus taurus, restrição alimentar, comportamento ingestivo, estabilidade do leite, comportamento social.

\section{INTRODUCTION}

Feeding restriction is a common situation during the cold season, when tropical and subtropical forages' development is reduced, or even in the summer, due to drought periods. The negative effects are accentuated in developing countries as Brazil, since a large amount of milk producers don't utilize hay or silage in periods of pasture shortage (CARVALHO et al., 2006). Underfeeding in lactating dairy cows is often associated with reduction in dry matter intake and milk production and this fact seems to be well known. Negative energy balance provoked by undernutrition may elevate cortisol levels (MORGAN \& TROMBORG, 2007), make animals more prone to development diseases (BERTONI et al., 2009) and compromise immune function (CARROLL \& FORSBERG, 2007). \footnotetext{
marcelo.stumpf@furg.br. Corresponding author.

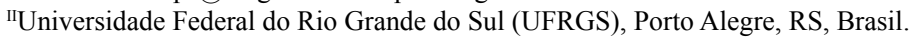

IIIEmbrapa Clima Temperado, Pelotas, RS, Brasil.

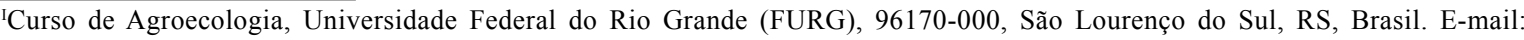


Although physiological and ingestive alterations can be detected, the first response of animal to stress is the behavioral one, which is the most efficient way to try to cope with the situation in terms of biological costs (MOBERG, 2000). Lying time, for instance, may be reduced due to low feed supply (HOFFMAN et al., 2007), and cows' welfare may be impaired by this event itself. Other negative behaviors can arise when cattle don't spend much time consuming their feed or when feed provision is not adequate with their requirements. The reduction in the provision of food is associated with elevated aggressive "reaching" to obtain food (HOFFMAN, 2007). HOFFMAN et al. (2007) reported aggressive behavior in heifers under limited feeding as well as increased vocalization levels. Besides that, increases in the incidence of oral stereotypies can occur when the foraging behavior is redirected into other activities due to the lack of food (LAWRENCE \& TERLOUW, 1993).

Milk characteristics, such as ethanol stability of milk (ZANELA et al., 2006), can also be altered due to feed restriction. Stability can be altered due to lactation stage (TSIOULPAS et al., 2007a), ionic calcium content in milk (TSIOULPAS et al., 2007b), alterations in the permeability of mammary gland cells tight junctions (STUMPF et al., 2013), among others. Milk stability to the ethanol test is of great importance for milk producers and dairy industries, especially in developing countries such as Brazil, Uruguay, Argentina, Taiwan and Russia since it defines milk suitability for industrial processing - milk with reduced stability is considered unsuitable and is not collected by dairies. Despite its impact in farmers' income, there are no easy and practical ways to detect animals that are more prone to produce milk with reduced stability. Thus, this study was conducted to perceive behavioral changes in underfed cows and find those that could serve as indicators of cows more prone to produce milk with reduced stability to the ethanol test.

\section{MATERIALS AND METHODS}

The study was conducted at Embrapa Clima Temperado, in Capão do Leão, Rio Grande do Sul, Brazil, between January and February of 2011. Daily temperature and relative humidity ranged from $13.19^{\circ} \mathrm{C}$ to $35.14^{\circ} \mathrm{C}$ and from $32.20 \%$ to $92.40 \%$, respectively. Twelve Jersey cows were housed in Free-stall barn with sand beds during the five weeks of experiment. During the first two weeks (adaptation period) all animals received a diet that met their nutritional demands (full diet, according to NATIONALRESEARCHCOUNCIL, 2001). The third week (Period 1) was the restriction period, when cows were divided into two homogeneous groups of six cows each, Control and Restriction groups, according to body weight, body condition score (BCS), days in milk, milk production and lactation periods. In this period, Control group continued receiving the former diet; Restriction group, on the other hand, received a restricted diet, consisting in $50 \%$ of the full diet. The two groups of cows were settled side by side in the barn and they had visual access to each other. Weeks 4 (Period 2) and 5 were the refeeding period, when all twelve cows received the full diet. Full diet was composed of $15 \mathrm{~kg}$ sugar cane silage; $5.8 \mathrm{~kg}$ alfalfa hay; $0.16 \mathrm{~kg}$ mineral salt and $6.2 \mathrm{~kg}$ concentrate $(3.3 \mathrm{~kg}$ of soybean; $2.6 \mathrm{~kg}$ of corn; $240 \mathrm{~g}$ of bicalcic phosphate and $14 \mathrm{~g}$ of $\mathrm{CaCO}_{3}$ ) per animal and per day. Cows were fed twice a day, at $08 \mathrm{~h} 00$ and $17 \mathrm{~h} 00$, with the use of headlocks. Animals were kept in headlocks until all food was consumed or until the animal was satiated and stopped eating. In the latter case, food leftovers became available for the rest of the respective group, since headlocks were opened. All animals had free access to fresh water during the whole trial.

At the end of week 2, before feed restriction starts, cows in the Restriction group had an average body weight of $372 \pm 39 \mathrm{~kg} ; 2.7 \pm 0.10$ of BCS; $145 \pm 39$ days in milk; $12.1 \pm 2.4 \mathrm{~L}$ day $^{-1}$ milk production and $3.3 \pm 1.5$ lactation periods. Cows in the Control group showed $372 \pm 33 \mathrm{~kg}$ body weight; $2.7 \pm 0.13$ of $\mathrm{BCS}$; $145 \pm 44$ days in milk, $12.3 \pm 2.5 \mathrm{~L} \mathrm{day}^{-1}$ milk production and $3.2 \pm 1.7$ lactation periods.

Blood samples were collected via jugular puncture in $10 \mathrm{~mL}$ heparinized and non-heparinized vacutainers on experimental days 15 and 21 (first and last days of Period 1). A veterinarian doctor performed this procedure after the morning milking and before feeding supply. Immediately after sampling all samples were centrifuged (Fanem, model 204NR) at 2,000 x g for 15 minutes. Plasma was aliquoted into $2.0 \mathrm{~mL}$ Eppendorf tubes and stored at $-20^{\circ} \mathrm{C}$ until analysis. Cortisol levels were analyzed from non-heparinized vacutainers by chemiluminescence to assess animals stress condition. To try to explain the reasons for possible variations in milk stability between groups of cows, the permeability of mammary gland cell tight junctions was analyzed through lactose content in plasma from heparinized vacutainers, which was determined with the use of an enzymatic assay kit [(Lactose Assay Kit - BioVision Research Products, Mountainview, CA, USA) in a microplate reader (Bio-Tek Instruments, model EL808 Micro-plate Reader (Winooski, USA)].

Cows behavior cows was monitored by visual inspection of each animal on the first and fifth days of Period 1 [days 15 and 19 of the experiment] and Period 2 [days 22 and 26 of the experiment], at every 10 minutes, 
between $08 \mathrm{~h} 40$ and $19 \mathrm{~h} 00$, totaling 63 observations $(630$ minutes) each day. For each cow, the activity performed at every 10 minutes interval was recorded and classified into: ingestive behavior: total eating time, time spent in ruminations while lying, time spent in ruminations while standing, total rumination time (rumination while lying + rumination while standing) and number of meals (number of occasions when cows moved to the feeding alley and consumed the feed); social behavior: number of agonistic interactions (aggressive physical contact, such as pushing and butting), number of vocalizations, number of stereotypies (such as tong-rolling, bar-biting) plus adaptive behaviors (such as salt bunk licking, floor licking, sand smelling, digging and eating besides pressuring the head against the wall or metal bars), time spent standing, time spent lying and total idleness time [630 - (total eating time + total rumination time + time spent by employers to clean the free-stall + time spent in milking + time spent in experimental procedures)]. To determine the time spent by each animal in the total eating time, total rumination time, time spent standing and time spent lying categories, it was assumed that the animal stayed performing the same activity between observations, so the number of observations in which the animals were performing each activity was multiplied by 10 . Activities such as number of meals, agonistic interactions, vocalizations, stereotypies and adaptive behavior were recorded whenever they occurred.

Milk was collected on the first and fifth days in Period 1 (experimental days 15 and 19) and Period 2 (experimental days 22 and 26) during morning and evening milking. The mixture of milk from both milkings formed one composed milk sample per cow per day. Samples were analyzed for stability to the ethanol test: in a Petri dish, $2 \mathrm{~mL}$ of milk was mixed with $2 \mathrm{~mL}$ of alcoholic solution (one concentration of alcohol at a time) with ethanol concentrations varying between 68 and $84^{\circ} \mathrm{GL}$ - results were expressed as the minimal ethanol concentration that induced coagulation of milk proteins; acidity by titration with $0.1 \mathrm{NaOH}$ solution; sodium content by atomic absorption spectrophotometry.

A Statistical Analysis System ${ }^{\circledR}$ package (v 9.2, 2009) was used. Despite the presence of only two groups (Control and Restriction), multivariate analysis (principal factors; PROC Factor) was performed to try to detect some relations and interactions that are not possible with the use of univariate analysis. In addition, the comparison between treatments was assessed through analysis of variance (PROC GLM). Significance level adopted was 5\% and trends towards significance were discussed at $10 \%$ probability. Increase in the odds of cows producing milk with reduced stability $\left(72^{\circ} \mathrm{GL}\right.$ or less) followed changes in behavior parameters was assessed with the use of logistic regressions (PROC Logistic). The $72^{\circ} \mathrm{GL}$ value represents the lower level of milk stability accepted by Brazilian's dairy industry.

\section{RESULTS AND DISCUSSION}

Principal factors (PF) analysis identified 5 PF. The first PF explained $39.77 \%$ of the total variance observed in the experiment and it was affected mostly by number of meals, time spent eating, idleness time and time spent standing (Figure 1); the second PF explained $19.66 \%$ of the total variance and it was influenced by feeding level, rumination while lying and agonistic interactions. The third, fourth and fifth PF explained together $40.57 \%$ of the variance in the experiment and were influenced, respectively, by standing rumination and total rumination time; milk sodium; cortisol levels. In figure 1 only the first two PF are represented. Results can be interpreted by the angle between vectors, where $90^{\circ}$ correspond to null correlation between variables, $0^{\circ}$ and $180^{\circ}$ correspond to high positive and negative correlations, respectively. Feeding level was positively correlated with milk stability to the ethanol test, total eating time, total rumination time and rumination while lying. Cortisol and plasma lactose levels, time spent standing, vocalizations, idleness time, agonistic interactions, rumination while standing and incidence of stereotypies plus adaptive behavior were negatively correlated with feeding level. Very low correlations were observed between feeding level, number of meals, titratable acidity, milk sodium and time spent lying.

Increased level of cortisol is reported for stressed animals and feed deprivation for two days may already induce this increase in cows (SAMUELSSON et al., 1996). In the present study the negative correlation between feeding level and cortisol levels in the PF analysis (angle of approximately $180^{\circ}$ ) evidenced the potential of severe dietary restriction on raising the levels of stress in cows. Since groups kept visual contact with each other, seeing Control cows with food still available may have frustrated Restriction cows, reducing their welfare.

Control and Restriction groups differed in some interesting parameters (Table 1). Restriction group presented reduced milk stability levels $(\mathrm{P}=0.0043)$, total eating $(\mathrm{P}=0.0010)$ and rumination times $(\mathrm{P}=0.0160)$ and time spent ruminating while lying $(\mathrm{P}=0.0035)$. This same group showed elevated time spent standing $(\mathrm{P}=0.0202)$ and idling $(\mathrm{P}=0.0021)$, higher occurrence of stereotypies plus adaptive behavior $(\mathrm{P}=0.0049)$, agonistic interactions $(\mathrm{P}=0.0002)$ and tended to vocalize more $(\mathrm{P}=0.0901)$.

Restriction group had $50 \%$ of the feeding level of Control cows, but they reduced their total eating 


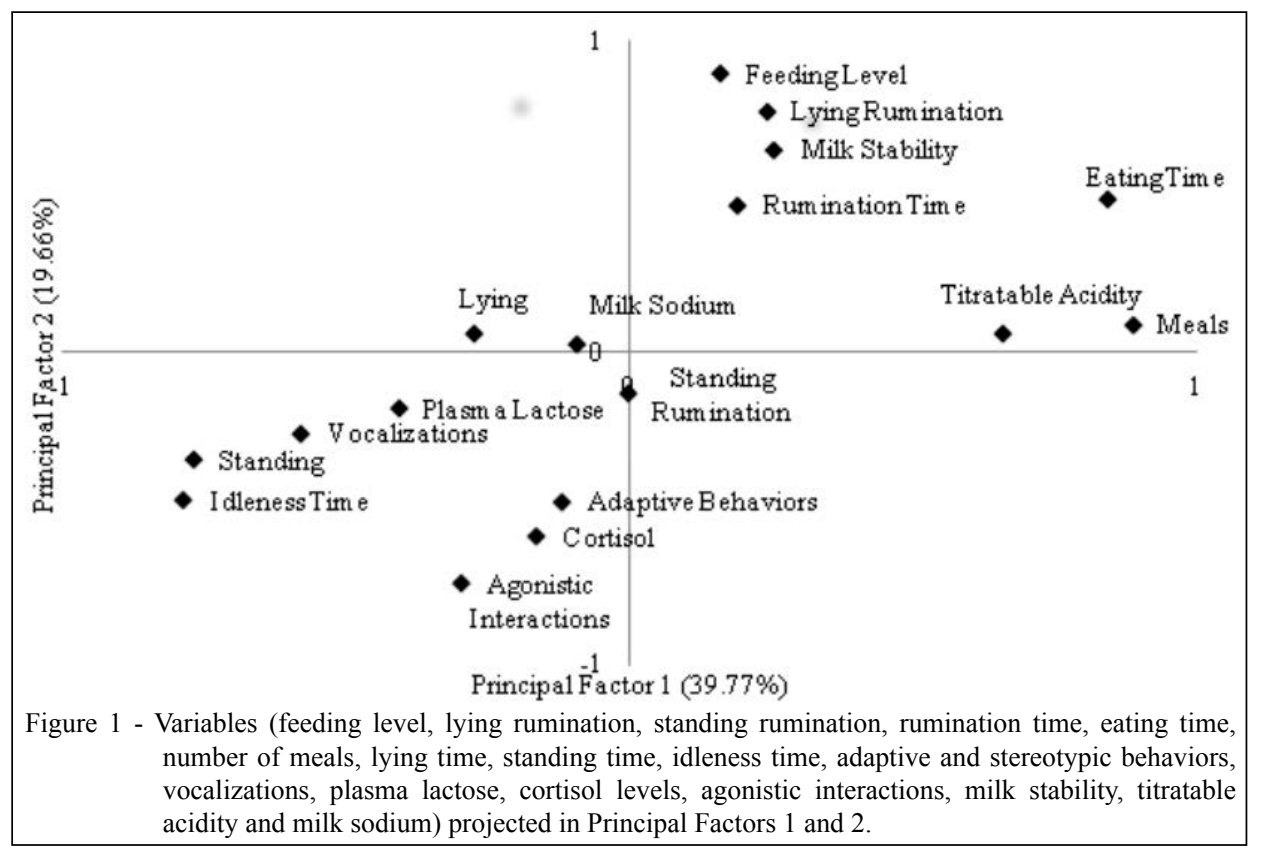

time in approximately $40 \%$, showing a faster eating rate. TUCKER et al. (2009) subjected Holstein-Friesian cows to a reduction of $50 \%$ in dry matter intake for 14 consecutive days and also observed reduction in eating time. Number of meals was unaffected by feeding

Table 1 - Mean values for cortisol levels, milk attributes and behavioral parameters in Jersey cows in Control and Restriction groups with corresponding significance levels.

\begin{tabular}{|c|c|c|c|}
\hline & Control & Restriction & P value \\
\hline Cortisol $\left(\mu \mathrm{gdl}^{-1}\right)$ & $0.43 b$ & $0.66 \mathrm{a}$ & 0.035 \\
\hline Milk stability $^{\mathrm{a}}$ & $76.33 \mathrm{a}$ & $70.67 b$ & 0.0043 \\
\hline Titratable acidity $\left({ }^{\circ} \mathrm{D}\right)$ & 16.16 & 15.00 & ns \\
\hline Time standing (min) & $133.33 b$ & $186.67 \mathrm{a}$ & 0.0202 \\
\hline Time lying (min) & 102.50 & 109.16 & ns \\
\hline Number of meals & 4.50 & 3.67 & ns \\
\hline Total eating time (min) & $264.17 \mathrm{a}$ & $160.83 b$ & 0.0010 \\
\hline Total rumination time (min) & $127.50 \mathrm{a}$ & $97.50 \mathrm{~b}$ & 0.0160 \\
\hline Rumination while standing (min) & 87.50 & 86.67 & ns \\
\hline Rumination while lying (min) & $40.00 \mathrm{a}$ & $10.83 b$ & 0.0035 \\
\hline Idleness time (min) & $138.33 b$ & $271.67 \mathrm{a}$ & 0.0021 \\
\hline Agonistic interactions $\left(\mathrm{n}^{\circ}\right)$ & $0.00 \mathrm{~b}$ & $1.41 \mathrm{a}$ & 0.0002 \\
\hline Vocalizations $\left(\mathrm{n}^{\circ}\right)$ & 0.00 & 0.33 & 0.0901 \\
\hline $\begin{array}{l}\text { Stereotypies plus adaptive } \\
\text { behaviors }\left(n^{\circ}\right)\end{array}$ & $0.50 \mathrm{~b}$ & $2.25 \mathrm{a}$ & 0.0049 \\
\hline
\end{tabular}

$\mathrm{ns}=$ non significant; Means followed by different letter in the row are statistically different in the Tukey test at $5 \%$ probability.

${ }^{\mathrm{a}}$ Concentration of ethanol capable of causing coagulation of milk proteins. restriction, which agrees with PF results and indicated that Restriction animals were able to manage reduced feeding allowance by distributing their consumption during the day. On the contrary, CÂNDIDO et al. (2012) subjected heifers to a $40 \%$ feeding restriction and observed a reduction from 4.12 to 2.34 meals per day.

As total rumination time is influenced by rumen fill, it was to expect that results from Control group would be higher. Principal factor analysis shows that the angle between feeding level and total rumination time was almost $0^{\circ}$, indicating a very strong and positive relation. BRISTOW \& HOLMES (2007) observed a tendency for reduced rumination in Angus/Hereford cows with increased cortisol concentration in blood; this same effect was perceived in the present experiment in univariate (elevated cortisol in Restriction group) and multivariate analysis - angle between cortisol and total rumination time was almost $180^{\circ}$ in PF analysis. Analysis of variance indicated that cows with increased feeding level spent more time ruminating while lying; PF showed that cows with increased feeding level spent less time ruminating while standing. Time spent standing up was also elevated in cows with reduced feeding level in PF (angle of approximately $180^{\circ}$ ) and analysis of variance. Both results may be due to the increase physical activity in animals under restriction, a response commonly interpreted as a sign of hunger and frustration (DE JONG et al., 2002).

The similarity in time spent lying between treatments and the almost null correlation between 
time lying and feeding level in PF is probably a reflection of a trade-off between eating and lying, in which cows with reduced feed intake spent less time eating (positive correlation between feeding level and total eating time in PF) and increased time lying, as also noted by TUCKER et al. (2009).

Restrictions in food supply in animals under confinement may directly cause an increase in the incidence of agonistic interactions and this may be caused by the competition for food and by frustration (METZ, 1983). Cows were fed with the use of headlocks; even so, some cows were able to release themselves, engaging against other cows in an attempt to take their space in the feeding alley. This event can cause a chain reaction and explain the higher number of aggressive interactions in Restriction group, what is confirmed by PF analysis

Feed consumption, rumination and idleness are mutually exclusive, and a reduction in time spent in the first two activities would imply in an elevation in idleness time. In accordance, total idleness time in the present experiment was elevated in Restriction group. Principal factors analysis is in agreement with these results.

High levels of stereotypies can indicate the level of animals' stress (MORGAN \& TROMBORG, 2007). Moreover, in animals kept indoors with restricted access to food, once all the diet is consumed, foraging behavior is redirected into other activities and may become stereotypic (LAWRENCE \& TERLOUW, 1993). Both PF and analysis of variance showed that cows receiving greater amounts of food manifest less those behaviors.

The tendency of higher incidence of vocalizations in cows with reduced feed intake $(\mathrm{P}=0.0901)$ is in agreement with $\mathrm{PF}$ results, which might be interpreted as cows trying to attract the feeder (MANTEUFFEL et al., 2004), as a direct signal of hunger. TUCKER et al. (2009) registered an increase in the number of vocalizations from cows under feeding restriction, but at higher rates than the present study. Even being significantly superior in Restriction group, the frequency of vocalizations was low. We hypothesized that animals were in some extent used to periods of lower feed supply, since the BCS prior to the study, an indicative of previous levels of feed intake, was low - approximately 2.5. Behavior parameters would probably be accentuated in animals with good BCS prior to the feeding restriction.

Titratable acidity was equal between treatments $(\mathrm{P}>0.05)$ and all results stayed inside the normal range according to Brazilian legislation (14 to $\left.18^{\circ} \mathrm{D}\right)$. Besides that, PF analysis showed almost null correlation between feeding level and titratable acidity. This same affirmation can be made when correlating feeding level and milk sodium in PF analysis. Values for sodium in milk were highly variable within and between animals and mammary gland cell's tight junctions' opening might be involved in such results (STUMPF et al., 2013), which increases the inflow and/or outflow of this ion to the mammary gland.

As expected, higher feeding level was followed by elevations in the stability of milk to the ethanol test in analysis. This may be due to reduced permeability of mammary gland tight junctions in cows full fed (STUMPF et al., 2013), which can be attested by the negative correlation between feeding level and plasma lactose in PF, a reliable indicator of tight junctions opening (STELWAGEN et al., 2000).

To our knowledge, the present experiment is the first to relate behavioral parameters with milk stability to the ethanol test. Summarizing, animals spending more time standing and idling, with elevated number of agonistic interactions, stereotypies plus adaptive behaviors and vocalizations, reduced time ruminating, ruminating while lying and time eating are more prone to produce milk with reduced stability to the ethanol test.

The odds of cows producing milk with reduced stability (below $72^{\circ} \mathrm{GL}$ ) according to behavioral parameters was assessed through logistic regression, which was performed for number of meals and behavioral variables that differed between treatments. A 30 minutes increase in time standing and idling elevates the odds of cows producing milk with reduced stability in 1.420 and 1.400 units, respectively; 30 minutes reduction in time spent eating and ruminating elevated those odds in 1.452 and 3.924 units, respectively; reductions in one meal and a 30 minutes decrease in lying rumination increase this same odds in 5.502 and 2.759 units, respectively. Also, elevations in one stereotypy plus adaptive behavior and one agonistic interaction elevate the odds in 2.080 and 1.778 units, respectively. These results are in agreement with other statistical analysis.

The relation between behavior parameters and milk stability remains elusive, but mechanisms such as the increase in the permeability of mammary gland cell's tight junctions in stressed animals (STELWAGEN et al., 2000; STUMPF et al., 2013), which could be detected visually, might be a explanation for the findings and a scientific field yet to be explored.

\section{CONCLUSIONS}

Feeding restriction induces an elevation in the incidence of behaviors related with hunger, 
frustration and discomfort, which can be visually identified and used to predict animals more prone to produce milk with reduced stability to the ethanol test.

\section{ACKNOWLEDGEMENTS}

The study was supported with Conselho Nacional de Desenvolvimento Científico e Tecnológico (CNPq) grant.

\section{REFERENCES}

BERTONI, G. et al. Some new aspects of nutrition, health conditions and fertility of intensively reared dairy cows. Italian Journal of Animal Science, v.8, p.491-518, Mar. 2009. Available from: <http:// www.tandfonline.com/doi/pdf/10.4081/ijas.2009.491>. Accessed: Oct. 15, 2013. doi: 10.4081/ijas.2009.491.

BRISTOW, D.J.; HOLMES, D.S. Cortisol levels and anxiety-related behaviors in cattle. Physiology \& Behavior, v.90, p.626-628, mar. 2007. Available from: $<$ http://www.sciencedirect.com/science/article/ pii/S0031938406005026> Accessed: Apr. 23, 2015. doi: 10.1016/j. physbeh.2006.11.015.

CÂNDIDO, E.P. et al. Ingestive behavior of Guzerat and Sindhi heifers under the effects of feed restriction. Acta Scientiarium, v.34, p.297-303, Jul.-Sep. 2012. Available from: <http://periodicos.uem.br/ ojs/index.php/ActaSciAnimSci/article/view/14328>. Accessed: Apr. 23, 2015. doi: 10.4025/actascianimsci.v34i3.14328.

CARROLL, J.A.; FORSBERG, N.E. Influence of stress and nutrition on cattle immunity. Veterinary Clinics of North America: Food Animal Practice, v.23, p.105-149, Mar. 2007. Available from: $<$ http:// www.sciencedirect.com/science/article/pii/S0749072007000047>. Accessed: Feb. 11, 2015. doi: 10.1016/j.cvfa.2007.01.003.

CARVALHO, P.C.F. et al. Produção animal no bioma campos sulinos. Revista Brasileira de Zootecnia, v.35, p.156-202, 2006. Available from: <http://www.forragicultura.com.br/arquivos/ ProducaoanimanoBiomaCamposSulinos.pdf $>$. Accessed: Jan. 06, 2014

DE JONG, I.C. et al. Effects of restricted feeding on physiological stress parameters in growing broiler breeders. British Poultry Science, v.43, p.157-168, 2002. Available from: <http://www. tandfonline.com/doi/abs/10.1080/00071660120121355>. Accessed: Jul. 01, 2015. doi: 10.1080/0007166012012135.

HOFFMAN, P.C. The potential to limit feed dairy replacemen heifers. In: MINNESOTA NUTRITION CONFERENCE, 68. 2007, Minnesota. Anais... Minnesota: University of Minnesota, 2007. p.186-192.

HOFFMAN, P.C. et al. Limit feeding of gravid Holstein heifers: effect on growth, manure nutrient excretion, and subsequent early lactation performance. Journal of Dairy Science, v.90, p.946-954, Feb. 2007. Available from: $<$ http://www.journalofdairyscience.org/article/S00220302(07)71578-3/pdf>. Acccessed: Dec. 18, 2014. doi: 10.3168/jds. S0022-0302(07)71578-3.

LAWRENCE, A.B.; TERLOUW, E.M.C. A review of the behavioral factors involved in the development and continued performance of stereotypic behaviors in pigs. Journal of Animal Science, v.71, p.2815-2825, Oct. 1993. Available from: <https://www.animalsci encepublications.org/publications/jas/pdfs/71/10/2815?searcheesult=1>. Accessed: May 28, 2015. doi: 1993.71102815x.
MANTEUFFEL, G. et al. Vocalization of farm animals as a measure of welfare. Applied Animal Behaviour Science, v.88, p.163-182, sep. 2004. Available from: <http://www.sciencedirect. com/science/article/pii/S0168159104000565>. Accessed: Jun. 09, 2015. doi: 10.1016/j.applanim.2004.02.012.

METZ, J.H.M. Food competition in cattle. In: BAXTER, S.H. et al. Current Topics in Veterinary Medicine and Animal Science. Boston: Martinus Nijhoff, 1983. p.164-170.

MOBERG, G.P. Biological response to stress. In: MOBERG, G.P.; MENCH, J.A. (Ed.). The Biology Of Animal Stress. Wallingford: CABI Publishing, 2000. p.1-21.

MORGAN, K.N.; TROMBORG, C.T. Sources of stress in captivity. Applied Animal Behaviour Science, v.102, p.262-302, jul. 2007. Available from: <http://www.appliedanimalbehaviour. com/article/S0168-1591(06)00199-7/pdf>. Accessed: Apr. 14, 2015. doi: 10.1016/j.applanim.2006.05.032.

STELWAGEN, K. et al. Short communication: effects of isolation stress on mammary tight junctions in lactating dairy cows. Journal of Dairy Science, v.83, p.48-51, Aug. 2000. Available from: $<$ http://www. journalofdairyscience.org/article/S0022-0302(00)74853-3/pdf $>$. Accessed: Apr. 22, 2015. doi: 10.3168/jds.S0022-0302(00)74853-3.

STUMPF, M.T. et al. Severe feed restriction increases permeability of mammary gland cell tight junctions and reduces ethanol stability of milk. Animal, v.7, p.1137-1142, Jul. 2013. Available from: $<$ http://journals.cambridge.org/action/displayAbstract?fromPage $=$ online \&aid $=8925669 \&$ fileId $=$ S1751731113000128 $>$. $\quad$ Accessed: Nov. 16, 2014. doi: 10.1017/S1751731113000128.

SAMUELSSON, B. et al. Profiles of the hormones somatostatin, gastrin, CCK, prolactin, growth hormone, oxytocin and cortisol. II. In dairy cows that are milked during food deprivation. Livestock Production Science, v.46, p.5764, jul. 1996. Available from: <http://www.sciencedirect.com/ science/article/pii/0301622696000218>. Accessed: Jan. 29, 2015. doi: 10.1016/0301-6226(96)00021-8.

TSIOULPAS, A. et al. Changes in physical properties of bovine milk from the colostrum period to early lactation. Journal of Dairy Science, v.90, p.5012-5017, Nov. 2007a. Available from: <http:// www.journalofdairyscience.org/article/S0022-0302(07)71969-0/ fulltext>. Accessed: Aug. 03, 2014. doi: 10.3168/jds.2007-0192.

TSIOULPAS, A. et al. Effect of minerals on casein micelle stability of cows' milk. Journal of Dairy Research, v.74, p.167173, May 2007b. Available from: < http://www.ncbi.nlm.nih.gov/ pubmed/17291390>. Accessed: Mar. 07, 2014. doi: 10.1017/ S0022029906002330.

TUCKER, C.B. et al. Effect of milking frequency and feeding level before and after dry off on dairy cattle behavior and udder characteristics. Journal of Dairy Science, v.92, p.3194-3203, Jul. 2009. Available from: <http://www.journalofdairyscience. org/article/S0022-0302(09)70636-8/fulltext>. Accessed: Feb. 11, 2014. doi: $10.3168 /$ jds.2008-1930.

ZANELA, M.B. et al. Unstable nonacid milk and milk composition of Jersey cows on feed restriction. Pesquisa Agropecuária Brasileira, v.41, p.835-840, May 2006. Available from: $<$ http:// www.scielo.br/scielo.php? script $=$ sci_arttext\&pid $=\mathrm{S} 0100$ 204X2006000500016>. Accessed: Feb. 11, 2014. doi: 10.1590/ S0100-204X2006000500016. 